Studia i Materiały, 2014 (17): 54-61

\title{
The Coaching Maps - geneza innowacyjnego narzędzia
}

\begin{abstract}
Robert Geisler*
Celem artykutu jest analiza innowacyjnego produktu - The Coaching Maps - jego genezy $i$ wdrożenia, a powstatego $w$ wyniku badań naukowych $z$ zakresu socjologii gospodarki $i$ psychologii biznesu. Jest to swoistego rodzaju produkt adekwatny do kontekstu spotecznogospodarczego XXI wieku będacy wynikiem połaczenia pracy naukowej z doświadczeniem praktycznym w zakresie zarzadzania wiedza, szkoleń $i$ coachingu. Analiza studium przypadku dotyczy genezy powstania wspomnianej innowacji oraz procesu kreowania innowacji jako interaktywnego procesu spotecznego.
\end{abstract}

Słowa kluczowe: innowacja, coaching, szkolenia.

Nadesłany: 15.06.2014 | Zaakceptowany do druku: 31.08.2014

\section{The Coaching Maps - innovative tool, origin and implementation}

The aim of the article is analysis of the innovative product - The Coachng Maps - its origin and implementation. The tool was created as result of the research in economic sociology and business psychology. It is product relevant to contemporary social and economic context in 21 century as result of scientific research and practice regarding knowledge management, training and coaching. The analysis of case study concern origin of innovation and process building innovation as interactive social process. Implementation of the innovation will be the second part of the analysis, especially in the context of entrepreneurial model in 21 century.

Keywords: innovation, coaching, training.

Submitted: 15.06.2014 | Accepted: 31.08.2014

JEL: O31

Dr hab. Robert Geisler - Uniwersytet Opolski, Instytut Socjologii.

Adres do korespondencji: Uniwersytet Opolski, Instytut Socjologii, ul. Katowicka 89, 45-061 Opole; e-mail: rgeisler@uni.opole.pl. 


\section{Wstęp}

Dwudziesty pierwszy wiek stanowi radykalnie odmienny kontekst społeczno-gospodarczy dla praktyki zarządzania i przedsiebiorczości niż to miało miejsce jeszcze kilkadziesiąt czy nawet kilkanaście lat wcześniej. Jest to kontekst ryzyka, niepewności, elastyczności, nieskończonych możliwości, a zarazem kreatywności. Określony mianem postfordyzmu bądź ponowoczesności podkreśla przede wszystkim rolę innowacyjności w gospodarce. Innowacje tym samym stały się we współczesnej gospodarce źródłem rozwoju przedsiębiorczości. Wpisuja się niewątpliwie w model postfordowski, nowy typ organizacji gospodarki - produkcji i usług. By przedsiębiorczość mogła się rozwijać czy w ogóle istnieć, bazować winna na innowacjach, tworzeniu nowych produktów, usług, zmian organizacyjnych, gdyż w innym przypadku nie będzie zdolna do konkurencyjności na rynku.

Artykuł wpisuje się w nurt socjologii gospodarki oraz antropologii gospodarki. Zastosowaną metodą badawczą w niniejszych analizach jest obserwacja uczestniczaca, autoetnografia oraz analiza dokumentów (Denzin i Lincoln, 2009). Etnografia to klasyczna metoda badawcza wykorzystywana w antropologii społecznej i kulturowej, a polegająca na opisie świata kultury, należałoby dodać - świata obcej kultury. Globalizacja i zmiany kulturowe końca XX i początku XXI wieku ukonstytuowały model, w którym z jednej strony żadna kultura nie była już obca a sami badacze znaleźli się w nurcie badań hybrydowych elementów kulturowych. Tym samym wykorzystywanie technik w badaniach etnograficznych, jak wywiady czy obserwacje, zaczęto wykorzystywać do analizy współczesnych form życia społecznego i struktur czy procesów społecznych, w tym również organizacji (Kostera 2010). Autoetnografia $\mathrm{z}$ kolei to obserwacja i analiza świata, którego się jest zarazem uczestnikiem. Autor niniejszego opracowania jest socjologiem gospodarki i jednocześnie współzałożycielem firmy Reflexive oraz współtwórcą innowacyjnego narzędzia rozwojowego The Coaching Maps. Odgrywanie tego rodzaju ról społecznych, badacza i przedsiębiorcy oraz autora innowacyjnego narzędzia, pozwala na generowanie wiedzy z różnych sfer życia oraz dokonywanie interpretacji i wyciąganie wniosków z wykorzystaniem syntezy, co zostało wykorzystane w niniejszym artykule.

Celem artykułu jest przedstawienie genezy innowacyjnego produktu - The Coaching Maps - powstałego w wyniku badań naukowych z zakresu socjologii gospodarki i psychologii biznesu. Jest to swoistego rodzaju produkt adekwatny do kontekstu społeczno-gospodarczego XXI wieku, będący wynikiem połączenia pracy naukowej $\mathrm{z}$ doświadczeniem praktycznym w zakresie zarządzania wiedzą, szkoleń i coachingu.

\section{Dlaczego powstało innowacyjne narzędzie?}

Innowacyjne narzedzie rozwojowe The Coaching Maps powstało w wyniku analizy dotychczasowej: (a) wiedzy na temat narzędzi coachingowych i szkoleniowych, (b) wiedzy na temat metod uczenia sie i kształcenia oraz (c) wiedzy o wyzwaniach współczesnego świata. Przede wszystkim trenerzy oraz coachowie podkreślali stały i skończony zestaw narzędzi do pracy ze swoimi klientami. Oznacza to, że pracując, nieustannie napotykali oczekiwania ze strony klientów skierowane na wykorzystywanie przez nich coraz to nowych narzedzi. W praktyce trenerzy i coachowie stanęli przed wyzwaniem konieczności nieustannego rozwijania swojego warsztatu, gdyż ich klienci, nawet pracując z innym coachem czy trenerem, wykonywali znane już im wcześniej ćwiczenia. Paradoksalnie, firmy kierujące swoje oczekiwania w stosunku do trenerów bardzo często formułowały negatywne oczekiwania, czyli czego by nie chciały podczas szkoleń, co jednocześnie stanowiło niejednokrotnie jedyną oferte firm szkoleniowych.

Narzędzie to powstało jako element przewagi konkurencyjnej nowych trenerów i coachów na rynku. Przede wszystkim w tym przypadku przyjęli oni założenie, że wchodząc na rynek, w którym funkcjonuja już coachowie i trenerzy $z$ wieloletnim doświadczeniem, warto mieć choć jeden element odróżniajacy i nie powinien on być brakiem doświadczenia czy też „świeżością" w porównaniu do innych. Dlatego też u autorów narzędzia pojawiła się idea skonstruowania czegoś nowego, nowego narzędzia do pracy.

Narzedzie to zostało nazwane The Coaching Maps - mapy umiejętności 
coachingowych, jako narzędzie do pracy podczas coachingu, szkoleń, doradztwa, opierające się na kreatywności oraz wewnętrznych potencjałach tkwiących w autorach. Wykorzystano wiedzę o wyzwaniach współczesnego świata będącą rezultatem badań i analiz oraz wiedzę z zakresu uczenia i metodyki kształcenia. W związku z powyższym innowacja odnosi się do wiedzy, jej generowania i kreowania nowych form $\mathrm{w}$ oparciu o istniejące już zasoby. Tym samym innowacja wpisuje się w model gospodarki opartej na wiedzy, gdyż staje się przedmiotem kupna-sprzedaży na rynku.

\section{Co to jest The Coaching Maps?1}

The Coaching Maps stworzone zostało do pracy nad kompetencjami odnoszącymi się do wiedzy, umiejętności i postaw wobec warunków i wymogów dzisiejszego świata. Warto zauważyć, że kompetencje wpływają bezpośrednio na podejmowane przez nas działania, na stosunek wobec wyzwań oraz oddziałują na tworzone przez nas relacje interpersonalne. Od posiadanych przez ludzi kompetencji zależy bowiem nasz rozwój, sposoby radzenia sobie z nowymi sytuacjami oraz sposoby nabywania nowej wiedzy i kształcenia nowych umiejętności. Wobec powyższego zadaniem The Coaching Maps jest przede wszystkim stworzenie okazji do uświadomienia sobie, oceny i rozwoju najbardziej pożądanych współcześnie kompetencji.

Narzędzie składa się z zestawu 36 map coachingowych, kompletu tematycznych fotografii oraz dwóch zestawów kart karty metafor i karty postaw. Zestaw 36 map coachingowych to zestaw naszkicowanych rysunków stanowiących punkt wyjścia do nadania indywidualnych znaczeń, a tym samym do stworzenia obrazu odpowiadającego własnym potrzebom. Ponadto narzędzie to komplet 36 tematycznych fotografii dobranych w sposób celowy, będących podstawą do stworzenia The Coaching Maps. $\mathrm{Na}$ wszystkich fotografiach przestawione zostały obrazy nawiązujące w sposób symboliczny do wybranych obszarów tematycznych. Oprócz tego w skład narzędzia wchodzi zestaw 36 kart metafor i komplet 36 kart postaw. Zestaw kart metafor przeznaczony jest do pracy opartej na myśleniu symbolicznym, metaforycznym, a tym samym do pracy na wartościach. Na każdej karcie metafor znajduje się specjalnie opracowany scenariusz do pracy z mapą coachingową odpowiadającą wybranemu tematowi. Scenariusz tworzą nazwy różnych symboli wynikające $\mathrm{z}$ obrazu danej mapy coachingowej oraz propozycja ich znaczenia. Komplet 36 kart postaw przeznaczony jest z kolei do pracy na poziomie trzech aspektów postaw, tj. poznawczego, emocjonalnego oraz behawioralnego. Karty postaw nadają się również do pracy w obrębie przekonań, ułatwiając dotarcie do nich i refleksje na ich temat. Na każdej karcie postaw została umieszczona właściwa dla niej nazwa, hasło przewodnie oraz określony cel jej zastosowania. Ponadto na wszystkich kartach postaw znajdują się pytania coachingowe odnoszące się do sposobu, w jaki postrzegamy i myślimy, w jaki odczuwamy i w jaki działamy w kontekście wyznaczonego obszaru tematycznego.

\section{W jaki sposób powstały The Coaching Maps?}

Na wstępie powstaje pytanie o źródła pojawienia się The Coaching Maps. Narzędzie powstało w wyniku analiz doświadczeń firm i ludzi, którzy osiągnęli sukces zawodowy i osobisty we współczesnym świecie. Analizy te w pierwszej kolejności dotyczyły cech współczesności, po wtóre funkcjonowania w tym czasie przedsiębiorstw i ludzi.

Czym jest współczesność? „Obyś żył w ciekawych czasach", jak mówi starożytna chińska klątwa i ta ciekawość świata jest często współcześnie podkreślana, pomimo że prawie każde pokolenie w historii podkreślało ciekawość ich czasów. Współczesność, czyli XXI wiek są jednak naprawdę ciekawe ze względu na dynamikę zmian i częstość pojawiania się czegoś nowego. Peter Drucker napisał kiedyś, że tylko zmiana jest pewna, a jej pojawianie się dzisiaj we wszystkich obszarach życia skutkuje koniecznością nowego sposobu myślenia i działania. Menedżerowie zarządzają dzisiaj w innych warunkach niż ich rodzice $\mathrm{w}$ dobie fordyzmu, pracownicy wykonują swoje czynności zawodowe w innych warunkach, niż kilkadziesiąt lat temu nauczyli się w szkołach.

Czym są wobec tego nowe warunki? Współczesny świat to świat zmian technologicznych, ekonomicznych, społecznych i kulturowych. Zmiany technologiczne to nieustanne innowacje w zakresie technologii organizującej nasze życie społeczne. 
Nowe oprogramowanie komputerowe, nowe rozwiązania w technologii oparte na wynalazkach w zakresie fizyki czy chemii to nieliczne tylko przykłady otaczającej nas rzeczywistości. Technologia niewątpliwie zmienia świat gospodarki - dominują w nim produkty i usługi niematerialne, oparte na wiedzy i informacjach przy wykorzystaniu zdobyczy techniki, a nie produkcja węgla i stali, czyli przedmiotów materialnych, jak to miało miejsce w XX wieku (Amin 2003, Barber 1997; Beck, Giddens i Lash 2009; Beck, 2002; Castells, 2007; Held i McGrew, 2003; Toffler, 2007; Thurow, 1999).

Gospodarka XXI wieku jest zorganizowana w inny sposób niż ta XX-wieczna w graniach państw narodowych. Nie potrzeba już zarządzanych centralnie wielkich fabryk o hierarchicznej strukturze. Konieczne jest jednak zbudowanie sieci relacji współpracujących ze sobą ludzi i firm. W rezultacie pojawiają się zmiany społeczne i kulturowe - nowy model wykonywania pracy - szczególnie tej w usługach wykorzystującej nowe technologie, nowy model kształcenia, nowy model związków międzyludzkich czy wreszcie nowy wzór zachowań. Jednym słowem - nowy typ mentalności (Sennett, 2006; 2010). Zmiana to niezmienny element krajobrazu wspó1czesnego świata. Odpowiedzią na niego jest jego złożoność, dynamika i wzrost elastyczności. Z kolei Donald Sull (2009) określił nasze czasy erą turbulencji, co rodzi skutki w postacie konieczności zarzadzania we mgle, relatywnie szybkim i skutecznym reagowaniem na wydarzenia $\mathrm{z}$ otoczenia, co wymaga $\mathrm{z}$ kolei nowego modelu przywództwa.

Jaki wobec tego jest współczesny świat? Jest to świat $\mathrm{z}$ panującym wszędzie ryzykiem w obszarze gospodarczym polegającym m.in. na nierównowadze handlowej, w obszarze środowiskowym dotyczącym emisji gazów, w sferze geopolitycznej odnoszącym się m.in. do niestabilnych relacji między państwami i organizacjami, np. terroryzmu. Obok ryzyka pojawia sie niepewność dotycząca przede wszystkim braku poczucia bezpieczeństwa i braku przewidywalności. W okresie powojennym pracownicy kopalń i hut, wychodzac do pracy, mieli poczucie, że odejdą z tej samej fabryki za kilkadziesiat lat na emeryture. Dzisiaj żadna firma nie daje swoim pracownikom poczucia stabilności, a jej produkty charakteryzuje krótki cykl życia. Wreszcie elastyczność to kolejna cecha współczesności związana z ryzykiem i niepewnością. Przedsiębiorstwa, jak i ludzie muszą nauczyć się żyć w nowych warunkach, a to oznacza, że musza odrzucić poczucie przewidywalności i pewności jutra na rzecz konieczności pojawiania się zmiany w ich życiu oraz przyjęcia tejże zmiany jako cechy stałej. Elastyczność to nic innego, jak tylko posiadanie umiejętności dokonywania zmian w swoim życiu do nowych warunków. Przedsiębiorstwa i pracownicy winni dostosowywać się do zmieniającego się wokół nich świata poprzez tworzenie nowych produktów, zmiany organizacyjne, funkcjonowanie w nowym środowisku czy też kreowanie nowych trendów (Bauman, 2006; 2007).

Ponieważ świat jest pełen nieustannie zachodzacych w nim zmian, niestabilności, ryzyka i niepewności, przedsiębiorstwa dostosowują się w swojej działalności do tego rodzaju cech: ciągle zmieniają swoje produkty czy usługi, strukture organizacyjną, zakres zadań, ale i cele czy metody pracy. Żadne $\mathrm{z}$ nich nie ma pewności trwania za kilkadziesiąt lat w tym samym modelu, co było cechą charakterystyczną firm XX wieku. Analizy współczesnych firm, które osiągają sukces rynkowy, pokazuja, że tylko te firmy, które potrafiły znaleźć się w nowych warunkach bądź też same kreowały te warunki, moga liczyć na przetrwanie, trwanie i rozwój. Natomiast odnalezienie sie przez firme w nowych warunkach $\mathrm{i}$ jej funkcjonowanie $\mathrm{w}$ nich oparte jest na ludziach: ich umiejętnościach, postawach, wartościach i ogólnie tożsamości. Skutki wyżej przedstawionych cech współczesnego świata dotyczą ludzi - przedsiębiorców, menedżerów i pracowników. Ten świat wymaga od nich nowego zestawu umiejętności, dzięki któremu będą mogli zarządzać firmami i nimi samymi, skutecznie pracować i wykorzystywać swoje możliwości (Amin, 2003; Sennett, 2006). Ten świat wymaga również nowej tożsamości człowieka, zbudowanej na innych fundamentach niż tożsamości człowieka XIX czy $\mathrm{XX}$ wieku. Badania menedżerów, przedsiębiorców i pracowników pokazują, że wymagany jest nowy zestaw cech współczesnego człowieka, do których zaliczyć można: innowacyjność czy kreatywność, elastyczność, zarządzanie sobą (czasem i zadaniami), umiejętności bycia liderem czy przewodzenia, tłumaczenie i dialog (szczególnie 
istotna cecha w wielokulturowym świecie), zdolność do ciągłego doskonalenia się (rozwój osobisty).

Z kolei amerykańscy badacze A. Davies, D. Fidler, M. Gorbis (2011) w książce Future Work Skills 2020 zdiagnozowali dziesięć kluczowych kompetencji koniecznych dla rozwoju współczesnych gospodarek oraz przedsiębiorstw osiagających przewage konkurencyjną. Zaliczyli do nich: zdolność do wyciągania ukrytego znaczenia, inteligencja społeczna, zdolność do adaptacji, kompetencje multikulturowe, myślenie analityczne, biegłość w obsłudze nowych mediów, transdyscyplinarność, nastawienie projektowe, zarządzanie poznaniem, współpraca wirtualna. Kompetencje te, zdaniem autorów, będa charakteryzować czy też w wymiarze normatywnym, powinny charakteryzować, pracowników i przedsiębiorców w najbliższych latach.

Kluczowe zatem pytanie, jakie zadają sobie zarządzający, jest pytaniem o wprowadzenie ww. cech w życie, czyli innymi słowy jest to pytanie o nową tożsamość człowieka, jej zmianę w przypadku występowania „starej” bądź zbudowanie jej od początku w przypadku osób wchodzących na rynek pracy czy rynek firm.

Podsumowując dotychczasowe rozważania, zmiany współczesnego świata wykreowały nowy model funkcjonowania firm czy też bardziej zmusiły je do adaptacji do niego, a to $\mathrm{z}$ kolei przyczyniło się do pojawienia się nowych cech przedsiębiorców, menedżerów i pracowników. Można wobec tego zadać praktyczne pytanie: jak zmienić ludzi? Przeprowadzone analizy firm - liderów we współczesnym świecie czy też z powodzeniem potrafiących nie tylko dostosować się do zachodzących zmian, ale i samemu je kreować, pokazują, że przedsiębiorstwa te zaczęły wdrażać z pracownikami programy szkoleniowe i coachingowe mające na celu zbudowanie nowych umiejętności czy też ukonstytuowanie nowej tożsamości człowieka. W wyniku tychże analiz powstał zbiór cech, które stały się nazwami kart.

Obok analiz cech charakterystycznych współczesnego XXI-wiecznego świata dokonano innego rodzaju badań, które dotyczyły analizy blogów coachów i trenerów zajmujących się wprowadzaniem zmian na poziomie organizacyjnym $\mathrm{i}$ jednostkowym - tożsamościowym. W wyniku tego pojawił się przede wszystkim wniosek o braku coachingu umiejętności. Niemniej jednak, by dokonać zmian w sferze umiejętności, potrzeba również dokonać zmian w sferze przekonań i tożsamości. Tożsamość człowieka to odpowiedź na pytanie - kim jestem? Najczęstsze odpowiedzi to: jestem kobietą/mężczyzną, Anglikiem/ Niemcem/Polakiem, ale i górnikiem, rolnikiem czy stoczniowcem. To ostatnie, czyli określanie siebie poprzez zawód dzisiaj przestaje mieć znaczenie, a w to miejsce pojawia się konieczność posiadania, i co ważniejsze, uświadamiania sobie posiadanych umiejętności czy kompetencji (Bauman, 2006; 2007). Zmiana w sferze przekonań i tożsamości wymaga pracy na innym, głębszym poziomie, co można zrealizować m.in. poprzez metaforę i symbolikę.

Metafora i symbolika nie są nowymi narzędziami w pracy coacha, doradcy czy trenera. Mają swoje źródła w hermeneutyce - przede wszystkim nurcie filozoficznym, ale i nurcie w literaturze, prawie czy teologii - polegającej na sztuce interpretacji tekstów. Założeniem hermeneutycznego myślenia jest ustalenie sensu i znaczenia, jakie są nam przekazywane przez innych. Użycie metaforycznego myślenia oraz symboli przez klientów czy osoby szkolone pozwala trenerowi czy coachowi na pokazanie ludziom ich ukrytych założeń leżących u podłoża myślenia i działania (Kurt, 2004). W ostatnich latach metafora i symbolika zostały wykorzystane m.in.: (1) przez karty szkoleniowe - bajki psychologiczne 1001 nocy; (2) narzędzie coachingowe The Points of You; (3) do gier symulacyjnych czy szkoleniowych proponowanych na rynku, a dotyczących zarządzania czy kształtowania umiejętności miękkich. Wspólną cechą stosowanych na rynku wymienionych narzędzi jest, po pierwsze, zastosowanie modelu gry, a po wtóre wykorzystanie modelu pracy na metaforze. Gra czy też zabawa zostały wykorzystane w ostatnich latach do modelu kształcenia dorosłych. Do tej pory przynależne dzieciom i dzieciństwu znalazły zastosowanie w uczeniu dorosłych ze względu na większy stopień przyswajalności materiału.

Natomiast model pracy $\mathrm{z}$ metaforą to również wykorzystywana często $\mathrm{w}$ społeczeństwach technika przekazywania wiedzy czy też ukazywania pożądanych zachowań. Tego rodzaju rolę odgrywają m.in. bajki czy baśnie o Czerwonym Kapturku, Królowej Śniegu czy Kopciuszku w świecie dzieci. 
W innych kulturach z kolei przekazuje się z pokolenia na pokolenie legendy, baśnie czy podania mające na celu pokazanie wartości dobra i zła czy innych cech normatywnych związanych z zachowaniami, a tym samym ma miejsce proces kształtowania tożsamości człowieka (Estes, 2001).

W obu przypadkach, czyli przypadku gry i metafory, mamy do czynienia z odejściem od realności, swoistego rodzaju ucieczką przed nią w celu przejścia w wyobrażony świat. Ten świat jest światem bardziej otwartym, pozbawionym często wyuczonych granic, jest krainą, gdzie człowiek może pozwolić sobie na puszczenie wodzy fantazji, a zarazem zapomnienie o codzienności. W obu przypadkach możliwa jest refleksja, ta jakże głęboka, odnosząca się do samoświadomości, gdyż związana z doświadczeniem, wewnętrznym przeżyciem mającym bardzo często dalekosiężne skutki. Wówczas to o wiele łatwiej dokonać jest zmiany umiejętności, przekonań czy nawet tożsamości człowieka.

Jednakże, by gra i metafora dały efekt w postaci zmiany umiejętności, przekonań i tożsamości potrzeba „żywego" narzędzia”, z którym można pracować. W tym przypadku pojawił się pomysł „mapy myśli”, również metody wykorzystywanej wielokrotnie i skutecznie zarazem w pracy z ludźmi. Mapowanie myśli to technika służąca nie tylko zapamiętywaniu, lecz także kreatywnemu tworzeniu nowych idei (Buzan, 2003). Oparta jest na budowie mózgu człowieka, który może wykorzystywać obie półkule do pracy twórczej, szczególnie prawą odpowiedzialną za wyobraźnię, kolory, przestrzeń i całościowe spojrzenie (Le Doux, 2000). Mape myśli można konstruować jako niezapisaną tablicę (tabula rasa), na czystej kartce dającej możliwości wypełnienia przestrzeni, zapełniając ją obrazami, hasłami, tezami, jak to ma często miejsce w przypadku burzy mózgów. Możliwe jest jednak również tworzenie mapy myśli w obrębie zadanego tematu, jakim może być obraz czy hasło przewodnie. $\mathrm{W}$ trakcie łączenia koncepcji mapy myśli z metaforą i symboliką, pojawiło się pytanie o punkt wyjścia do tworzenia mapy myśli. Odpowiedzi udzieliła wcześniej dokonana analiza rzeczywistości, czyli cech współczesnego świata i odpowiadających im cech współczesnego człowieka. Swiat nieustannej zmienności, ulotności, ryzyka i niepewności.
W związku z powyższym pojawiło się pytanie, jak stworzyć „mapy”? Otóż przyjęto, że zadane tematy mapy myśli powstaną jako odzwierciedlenie zdjęć w metaforyczny sposób oddające cechy współczesności. Zdjęcia to fotografie przygotowane przez człowieka charakteryzujace sie pożadanymi cechami współczesności. Mógłby on zostać uznany za lidera cech współczesności, z jego mobilnością, elastycznością, kreatywnością, umiejętnościami adaptacji w różnych warunkach, ale i wrażliwością na otaczający go świat czy dbającym o swój rozwój osobisty. Można dokonać interpretacji zdjęć jako oddających w metaforyczny sposób takie cechy, jak złożoność, porozumienie, aktywność, niepewność, ryzyko, przewidywalność czy samotność. To na ich podstawie przygotowano szkice - zarysowano jednak najistotniejsze rysy, niebedące jednakże repliką zdjęć ze względu na fakt, że odrzucenie wiernej kopii ma na celu jedynie zainspirowanie oraz ukazanie swobody interpretacji podczas pracy, a nie narzucanie schematu myślenia. W ten sposób powstały The Coaching Maps jako szkice i zdjęcia w sposób metaforycznie przedstawiający cechy współczesności, które można wykorzystać do pracy nad kreowaniem nowych umiejętności, przekonań i tożsamości ludzi żyjących w XXI wieku - wieku nieustannie zachodzących zmian.

\section{Do czego służą The Coaching Maps?}

The Coaching Maps można z powodzeniem wykorzystywać podczas coachingu, mentoringu, doradztwa, konsultingu oraz terapii. Pomocny może okazać się w trakcie szkoleń czy warsztatów, używany jako „lodołamacz” i „energizer”. Może on stać się podstawą dla opracowywania modułów szkoleniowych czy tworzenia gier biznesowych. Niezwykle przydatny może okazać się również jako narzedzie wykorzystywane do realizacji ćwiczeń, wykładów, prowadzenia dyskusji, jak i różnego rodzaju analiz. The Coaching Maps mogą znaleźć swoje zastosowanie również podczas procesu ewaluacji i oceny pracowników. Przeznaczone są także do pracy majacej na celu odpowiednie motywowanie i zarządzanie zasobami ludzkimi. Wierzymy, że użytkowanie The Coaching Maps okaże się pomocne w wielu formach związanych z rozwojem osobistym i zawodowym. 
Nie ulega wątpliwości, że charakteryzują nas różnorodne sposoby myślenia, przyswajania i przekazywania informacji. Nasza innowacyjność i kreatywność pozwala nam wychodzić poza utarte schematy, w zwiazku z czym należy pamiętać, że The Coaching Maps są tylko propozycją. Oznacza to, że można wykorzystać je jako inspiracje i podstawę do tworzenia własnych pomysłów.

\section{Innowacja na rynku - teraźniejszość i przyszłość}

Wykreowanie innowacyjnego narzędzia do pracy rozwojowej i szkoleniowej to część szeroko rozumianego procesu innowacyjności. Wdrożenie tej innowacji to drugi etap, może o wiele bardziej istotny, gdyż wówczas to innowacja staje się częścią życia społecznego i gospodarczego ${ }^{2}$. W tym przypadku, od chwili pojawienia sie innowacji na rynku, pojawiła się strategia marketingowa i sprzedażowa oparta przede wszystkim na modelu sieciowym (Naisbitt, 1997). W sposób jednoznaczny i świadomy zarazem odrzucono wszelkiego rodzaju sponsoring i reklamę jako metody marketingowe i reklamowe $\mathrm{z}$ uwagi na funkcjonowanie produktu w innej rzeczywistości niż fordowska (Alper, Babinski i Cesvet, 2010). Przyjęto bowiem założenie o cechach postfordowskiej rzeczywistości jako kluczowych w dobie XXI wieku, a tym samym aplikacji nowych metod sprzedaży.

Model sieciowy został zaproponowany w 1973 roku przez Marca Granovettera w pracy „The Strenght of Weak Ties" i zakłada wielość relacji społecznych opartych na bezpośrednim kontakcie pomiędzy ludźmi oraz przekazywaniu sobie w związku z tym informacji i wiedzy. Polega on na wykorzystaniu relacji pomiędzy ludźmi, ich znajomości, kontaktów do relacji biznesowych. W przypadku marketingu i sprzedaży można mówić o przekazywaniu sobie informacji i wiedzy o produkcie pomiędzy ludźmi z różnych organizacji czy środowisk społecznych w celu dotarcia do odbiorców. Warto w tym modelu podkreślić rolę kanałów komunikacji interpersonalnej w związku z przekazywaniem sobie wiedzy na temat produktu. Strategia modelu sieciowego wiąże się z podjęciem działań operacyjnych, jak prezentacje produktu podczas spotkań, warsztatów, szko- leń, wykonywanie pracy z wykorzystaniem narzędzia, zatrudnienie „Ambasadorów Produktu”, czyli osób multiplikujących wiedzę i informacje o produkcie.

Wdrożenie innowacyjnego produktu napotkało kluczowe zagrożenie, jakim był opór przed innowacją, przed jej zastosowaniem. Opór mógł być spowodowany kwestiami finansowymi, ale podczas rozmów z potencjalnymi klientami - odbiorcami produktu - pojawił się opór natury psychologicznej, związany z koniecznością nauczenia się czegoś nowego, poznania nowego narzędzia, a następnie wykorzystania go w swojej pracy.

Kluczowym z kolei wyzwaniem był fakt, że innowacyjny produkt dał impuls do przedsiębiorczości autorów. Pojawili się na rynku i zaczęli konsekwentnie realizowanie swoja strategie, dostosowujac ja nieustannie do zmieniających się okoliczności oraz dostosowując działania operacyjne do wniosków powstałych z nieustannie gromadzonej o rynku wiedzy. Sam proces działania to nieustanna analiza, generowanie nowej wiedzy i aplikowanie jej do bieżących działań. Przedsiębiorczość to nieustanny interaktywny proces uczenia się, tworzenia nowej wiedzy i testowania jej wyników w praktyce.

\section{Zakończenie}

Od zrodzenia się pomysłu do wyprodukowania narzędzia upłynęło 18 miesięcy. Zakończył się etap pracy koncepcyjnej, a rozpoczął etap wdrożenia związany z przedsiębiorczością. Kolejne miesiące to intensyfikacja prac promocyjnych opartych na przyjętej strategii. W tym okresie ma miejsce rozwój przedsiębiorczości oraz kreowania dalszych innowacji, tym razem już marketingowych, promocyjnych czy wręcz sprzedażowych. Istotne jest, że innowacja znalazła się na rynku i zaczyna żyć „własnym życiem”. Metodologia badań jakościowych pozwala z kolei autorom na wgląd we własną działalność oraz analizy swojej przedsiębiorczości. Zarzut braku obiektywizmu kierowany pod adresem tego rodzaju badań zostaje przeciwstawiony wiedzy eksperckiej autorów oraz znajomości studium przypadku „od podstaw”. Wykorzystanie jednak tego rodzaju metodologii może dać wgląd w proces kreacji i wdrożenia innowacji. 


\section{Przypisy}

1 W niniejszym podrozdziale wykorzystano informacje ze strony internetowej www.thecoachingmaps.eu.

2 W chwili pisania artykułu ma miejsce etap wdrożenia produktu na rynek, stąd możliwe jest jedynie zanalizowanie jego założeń.

\section{Bibliografia}

Alper, E., Babinski, T. i Cesvet B. (2010). Kapitat konwersacyjny. Jak tworzyć rzeczy, o których inni będa chcieli rozmawiać. Warszawa: Wolters Kluwer.

Ash, A. (red.) (2003). Post-fordism. A Reader. Oxford: Blackwell Publishing House.

Barber, B. (1997). Dżihad kontra McŚwiat. Przeł. H. Jankowska. Warszawa: Warszawskie Wydawnictwo Literackie MUZA SA.

Bauman, Z. (2006). Plynna nowoczesność. Przeł. T. Kunz. Kraków: Wydawnictwo Literackie.

Bauman, Z. (2007) Plynne życie. Przeł. T. Kunz. Kraków: Wydawnictwo Literackie.

Beck, U. (2002). Spoteczeństwo ryzyka. $W$ drodze do innej nowoczesności. Przeł. St. Cieśla. Warszawa Wydawnictwo Naukowe Scholar.

Beck, U., Giddens, A. i Lash, S. (2009). Modernizacja refleksyjna. Polityka, tradycja $i$ estetyka $w$ porzqdku społecznym nowoczesności. Przeł. J. Konieczny. Warszawa: Wydawnictwo Naukowe PWN.

Castells, M. (2007). Spoteczeństwo sieci. Warszawa: Wydawnictwo Naukowe PWN.

Cohen, R. i Kennedy, P. (2007). Global Sociology. Basingstoke: Palgrave.

Davies, A., Fidler, D. I Gorbis, M. (2011). Future Work Skills 2020. Phoenix: Institute for the Future for University of Phoenix Research Institute.

Denzin, N.K. i Lincoln, Y.S. (2009). Metodologia badań jakościowych. Red. nauk. K. Podemski. Warszawa: Wydawnictwo Naukowe PWN.

Descy, P. I Tessaring, M. (2002). Training and learning for competence. Second Report on Vocational Training research in Europe. Luxembourg: Office for Official Publications of the European Communities.

Drucker, P. (1999a). Spoleczeństwo pokapitalistyczne. Przeł. G. Kranas. Warszawa: Wydawnictwo Naukowe PWN.
Drucker, P. (1999b). Zarzadzanie w XXI wieku. Przeł. B. Kacprzyńska. Warszawa: Wydawnictwo MUZA SA.

Estes, C.P. (2001). Biegnaca z wilkami. Przeł. A. Cioch. Poznań: Wydawnictwo Zysk i s-ka.

EU. (2010). New Skills for New Jobs: Action Now. Brussels: European Union Commission.

Florida, R. (2004). The Rise of the Creative Class. And How its Transforming Work, Leisure, Community and Everyday Life. New York: Basic Brooks.

Granovetter, M. (1973). The Strenght of Weak Ties. American Journal of Sociology, 78(6), 1360-1380.

Held, D. I McGrew, A. (2003). The Global Transformation Reader. An Introduction to the Globalization Debate. Cambridge: Polity Press.

Kostera, M. (2010). Antropologia organizacji. Warszawa: Wydawnictwo Naukowe PWN.

Kurt, R. (2004). Hermeneutik. Eine sozialwissenschaftliche Einfuerung. Konstanz: UVK Verlagsgesellschaft $\mathrm{mbH}$.

Le Doux, J. (2000). Mózg emocjonalny. Tajemnicze podstawy życia emocjonalnego. Poznań: Wydawnictwo Media Rodzina.

Naisbitt, J. (1997). Megatrendy. Dziesięć kierunków zmieniających życie. Poznań: Zysk i s-ka.

Rifkin, J. (2001). Koniec pracy. Schytek sity roboczej na świecie i początek ery postrynkowej. Przeł. E. Kania. Wrocław: Wydawnictwo Dolnośląskie.

Rifkin, J. (2003). Wiek dostepu. Nowa kultura hiperkapitalizmu, w której ptaci się za każda chwilę życia. Przeł. E. Kania. Wrocław: Wydawnictwo Dolnośląskie.

Sennett, R. (2006). Korozja charakteru. Osobiste konsekwencje pracy $w$ nowym kapitalizmie. Przeł. J. Dzierzgowski i Ł. Mikołajewski. Warszawa: Warszawskie Wydawnictwo Literackie MUZA SA.

Sennett, R. (2010). Kultura nowego kapitalizmu. Przeł. G. Brzozowski i K. Osłowski. Warszawa: Warszawskie Wydawnictwo Literackie MUZA SA. Sull, D. (2009). How to Thrive in Turbulent Markets. Harvard Business Review, 2.

Thurow, L. (1999). Przyszłość kapitalizmu. Jak dzisiejsze sity ekonomiczne ksztattuja świat jutra. Przeł. L.Czyżewski. Wrocław: Wydawnictwo Dolnośląskie.

Toffler, A. i Toffler, H. (2007). Rewolucyjne bogactwo. Przeł. P. Kwiatkowski. Wrocław: Wydawnictwo Kurpisz S.A. 